\title{
Sonographic Evaluation of Urinary Tract in Patients with Abnormal Renal Function Tests and Urine Examination
}

\author{
Zainab Atta-ur-Rehman* \\ Superior University, Lahiore \\ Raiwind Road Lahore ,Pakistan \\ Hamid Shahbaz \\ Superior University, Lahiore \\ Raiwind Road Lahore ,Pakistan \\ Azhar Mehmood \\ Superior University, Lahiore \\ Raiwind Road Lahore ,Pakistan \\ Ali Hassan \\ Superior University, Lahiore \\ Raiwind Road Lahore ,Pakistan \\ Qamrosh Akhtar \\ Superior University, Lahiore \\ Raiwind Road Lahore ,Pakistan \\ Hira Riffat \\ Demonstrator at Superior University, Lahore \\ Rana Muhammad Athar Azeem Shams \\ Demonstrator at Superior University, Lahore \\ Rana Muhammad Bakhtawar Khan Sajawal \\ Demonstrator at Superior University, Lahore
}

\begin{abstract}
Background: Our study will provide reliable ways to diagnose Urinary tract abnormalities to health care professionals to further evaluate, follow up and surveillance of the pathology . Materials and methods: A crosssectional study included 71 patients with provisional diagnosis of Urinary Tract Diseases along with the associated clinical manifestations and study duration is 4 months.Results: Our results shows that among 71 patients, urinary tract diseases is recorded to be maximum in $40.21(57 \%)$ patients and minimum to be around 34 (44\%). In urine analysis out of 71 patients, creatinine level is increase in (24\%), echogenicity of right kidney was increased in (1.4\%) and bilateral echogenicity was noticed in (17\%). Serum urea level is abnormal in (59.1\%), echogencity of right and left kidney is increase in $(6 \%)$ and $(1.4 \%)$ respectively. Bilateral echogencity is notice in $(28 \%)$. Calcium oxalate Crystal level is present in $(28 \%)$ and hydronephrosis is increased in (15.4\%).Urinary bladder wall thickness is abnormal in (21\%) patients, many and fewer Red blood cells present in $(20 \%)$ and $(2.8 \%)$ respectively . Pus Cells are increase in (36.6\%), hydronephrosis is noted in (15.4\%).Patients have many and fewer pus cells $(15.4 \%)$ and $(17 \%)$ respectively.Conclusion: We concluded that ultrasound parameters with correlation of laboratory tests has significant credibility to detect urinary tract diseases .
\end{abstract}

Keywords: Renal Function Test,Urine analysis, Ultrasound.

DOI: $10.7176 / \mathrm{JHMN} / 90-14$

Publication date: June $30^{\text {th }} 2021$

\section{Introduction}

The most common diseases of kidney are renal calculus, hydronephrosis, ureteric calculus, renal cyst, prostatomegaly, cystitis, UB mass, urinary bladder obstruction, pyelonephritis, increased kidney echogenicity, residual urine, urinary tract infections (UTI), and gross hematuria $(\mathrm{GH}){ }^{(l)}$

Chronic kidney disease (CKD) is increasing in Pakistan. Overall, 21.2 percent of Pakistani adults had chronic kidney disease. The highest prevalence of CKD is (43.6\%) among elderly participants over 50 years of age, and the lowest prevalence among younger participants under 30 years of age $(10.5$ percent $) .{ }^{(2)}$

Renal function tests (RFTs) are used to evaluate renal function and are pivotal for the treatment of patients 
that have kidney failure or other pathologies that impair renal function. ${ }^{(3)}$ Renal function measures creatinine, urea, uric acid, and electrolytes and are useful in detecting the presence of renal disease, tracking the reaction of the kidneys to treatment, and evaluating the progression of renal disease. Until an increase in serum creatinine can be observed, about $50 \%$ of kidney function is loss as it helps in indicating of acute kidney injury. In acute and chronic renal disease, the amount of serum urea/BUN rises. ${ }^{(4)}$ Significant clinical conditions associated with renal glomerular and tubular functions include renal threshold, tubular secretion, reabsorption, renal endocrine functions, and glomerular filtration rate. ${ }^{(5)}$

Urine analysis is a reliable tool for improving kidney disease diagnosis. Because patients often sample urine specimens, urinalysis is prone to preanalytical problems. It can also detect signs of diabetes mellitus. ${ }^{(6)}$ In the presence of symptoms such as oedema and changes in urine composition in patients with renal failure, histological and functional renal decompensation are often missed due to a lack of symptoms. A elevated blood pressure with or without urinary anomalies detectable on urine analysis, such as microalbuminuria and proteinuria cells, and casts on urine microscopy, can be the only evidence of the existence of renal disease in an asymptomatic patient. ${ }^{(7)}$ The LE result as positive if any amount, including a trace amount, was detected. Nitrite results were defined as being negative or positive. The pyuria results as the presence of $>5$ white blood cells (WBCs) ${ }^{(8)}$ The three components of the urinalysis that were evaluated were LE, nitrite, and pyuria. ${ }^{(9)}$ Protein, blood cells, glucose, $\mathrm{pH}$, calcium oxalates, nitrites, and leukocyte esterase are all identified chemically in urine. ${ }^{(10)}$ Hematuria and proteinuria are the most common urinalysis abnormalities that lead to a referral to a paediatric nephrologist. (11)

Both ultrasonography and urinalysis are cost-effective screening methods for CKD in patients, and they could complement each other and play vital roles in the early diagnosis of urinary system abnormalities.(5) Cortical thickness should be recorded in patients with CKD who are not on dialysis. The specificity of ultrasound is 56.7 percent. ${ }^{(12)}$ In the evaluation of renal or urinary tract disease, ultrasound (US) should always be considered an authentic imaging modality. Ultrasonography (US) is a useful tool for visualising the urinary tract. ${ }^{(13)}$ Dr. Karl Theo Dussik, a neurologist from Austria, was the first to use ultrasound. ${ }^{(14)}$ Ultrasound (US) is a non-invasive and secure imaging modality for the medical and surgical fields. Ultrasound (US) is an easy and fast decision-making tool for patients with urinary or renal symptoms that need renal intervention. For imaging of the urinary tract, ultrasound is the most effective and preferred method. ${ }^{(15)}$

Our research will provide dependable methods for health care practitioners to assess, follow up on, and track urinary tract abnormalities, and will claim to provide accurate results in the diagnosis.

\subsection{Method:}

Materials and methods:

Study design: Analytical Cross-sectional Study.

Duration of Study: 4 months.

Sample size: 70 patients

Sampling technique: Non-convenient sampling

Inclusion Criteria:

- Male and female both above 18 years

- Patients done with RFTs and urine examination tests and showing symptoms of flank pain, pelvic pain, lower abdominal discomfort, chronic UTI

Exclusion Criteria

- Below 18 years

- Uncooperative patients

- normal urine examination

- Congenital renal abnormalities e.g. Polycystic kidney disease,, renal agenisis)

Data collection procedure: All patients of either sex suffering from flank pain, pelvic, lower discomfort, painful urination, chronic urinary tract infection, hematuria, pyuria, difficulty urination, urinary incontinence and their RFTs and urine examination tests done were included in the study. During this period 70 patients were selected on the basis of age, gender and radiological findings, informed, verbal consent was taken and ultrasonographic reports were collected from radiologist office and lab tests report for laboratory of Sheikh Zaid Hospital.

Data analysis: Appropriate statistical data analysis technique by using SPSS version 24.

\subsubsection{Discussion}

Discussion:

According to our results, creatinine is significant in our studies during urine analysis on ultrasound examination. We included 71 patients in our study, creatinine level was increased in 17(23.9\%) patients. Renal echogenicity was normal in 4(5.6\%) patients, echogenicity of right kidney was increased in $1(1.4 \%)$ patient and bilateral increased echogenicity was noticed in $12(17 \%)$ patients. Similar results seen in study conducted by Jagdeesh K. Siddapa et.al in (2013) on correlation on serum creatinine and chronic kidney disease with echogenicity. They 
included 60 selected patients, mean age 32 year. In which 42 were male and 18 were female.The mean serum creatinine was $2.8 \mathrm{mg} / \mathrm{dl}$ for Grade 1 (range: $0.9-9.2 \mathrm{mg} / \mathrm{dl}$ ), $3.69 \mathrm{mg} / \mathrm{dl}$ for Grade 2 (range: $1.2-10.3 \mathrm{mg} / \mathrm{dl}$ ), 3.86 $\mathrm{mg} / \mathrm{dl}$ for Grade 3 (range: 1.1-6.5 mg/dl), and $7.9 \mathrm{mg} / \mathrm{dl}$ for Grade 4 (range: 3.1-11.4 mg/dl). ${ }^{(16)}$ According to table no 2, serum urea is significant in our studies during urine analysis on ultrasound examination to evaluate the renal echogenicity. We included total of 71 patients, serum urea level was abnormal in $42(59 \%)$ patients. echogencity of right and left kidney was increased in 4(5.6\%) and 1(1.4\%) patients respectively. Bilateral increased echogencity was noticed in 20(28\%) patients. Similar results seen in study conducted by Angel Marcy-C Anakwue et.al in (2020) on prospective cross sectional study to evaluate the effects of chronic exposure to some petroleum products on kidney of exposed workers using sonography. They included 415 workers. The study population comprised 164 petrol station attendants, 175 automobile mechanics and 76 petrol tanker drivers aged between 20 and 65 years. Abdominal ultrasound was performed, as well as serum urea and creatinine .Increased echogenicity of the kidneys was observed in 21 subjects This study reports a significant increase in blood urea and creatinine levels in the exposed workers compared to controls. ${ }^{(17)}$ According to table no $3, \mathrm{CaO}$ crystals are significant in our studies during urine analysis on ultrasound examination. We included 71 patients, CaO Crystals was present in 20(28\%). Hydronephrosis was increased in 11(15.5\%) patients, hydronehprosis of right and left kidney was increased in $4(5.6 \%)$ and 2(2.8\%) respectively. Bilateral increased hydronehprosis was noticed in 3(4\%) patients. Similar results seen in study conducted by Saeed R. Khan et.al in (2004) on retrospective cross sectional study to evaluate crystal- induced inflammation of the kidney. They included Renal cellular exposure to oxalate (Ox) and/or CaOx crystals leads to the production of reactive oxygen species (ROS). CaOx crystal deposition in kidneys is significantly reduced by treatments with antioxidants. These results point towards an antioxidants and free radical scavengers to reduce stone recurrence particularly after shock wave lithotripsy, which is itself known to generate ROS and cause renal damage. ${ }^{(18)}$ According to table 4, urinary bladder wall thickness are significant in our studies during urine analysis and abnormal RFTs on ultrasound examination. We included 71 patients in our study, urinary bladder wall thickness was abnormal in 15(21.1\%) patients. Similar results seen in study conducted by Marjan Joudi et.al in(2011) on prospective cross sectional study to evaluate the incidence of asymptomatic meatal stenosis cusing thickness of urniary bladder wall. They included 132 male patients, mean age above to 18 years old. Of the 132 cases, $27(20.4 \%)$ had severe meatal stenosis (diameter $<5 \mathrm{~F})$. Thickening of the bladder and bilateral hydronephrosis (pyelocaliceal) were found in three cases $(11.1 \%)$, and a voiding cystourethrogram was performed to reveal vesicoureteral reflux (VUR). ${ }^{(19)}$ According to table 5 , RBCs are significant in our study during urine analysis on ultrasound examination. We included a total of 71 patients, hematuria was present in $16(23 \%)$ patients.many RBCs present in $12(20 \%)$ patients, $2(2.8 \%)$ patients have fewer RBCs. Similar results seen in study conducted by Peter R. MD et.al in (2000) was performed a prospective, controlled study to determine the ability of clinicians to assess gross hematuria. They conducted some tests to collect 3500 RBCs. Gross hematuria was recognized by more than $95 \%$ of clinicians only when samples contained more than 3,500 red blood cells per highpower field $(\mathrm{p}>0.08)^{(20)}$. According to table 6 , Pus cells are significant in our study during urin analysis on ultrasound examination. We included 71 patients, Pus Cells was increased in 26(36.6\%) patients. hydronephrosis was increased in 11(15\%) patients, Hydronephrosiis of right and left kidney was increased in 6(8.5\%) and 3(4.2\%) respectively. Bilateral increased hydronephrosis was noticed in $6(8.5 \%)$ patients. Similar results seen in study conducted by Abdullah Erdogan et.al in (2020) performed retrospective cross sectional study on urinary system obstruction to evaluate hydronephrosis. They included 159 patients and 214 renal units. Hydronephrosis was detected in 176 renal units and pyonephrosis in 38 renal units. No statistically significant difference was observed between the measured AP diameter and renal pelvic area in the two groups $(28.45 \pm 10.1 \mathrm{~mm}$ vs. $31.13 \pm 14.4 \mathrm{~mm}$, $\mathrm{p}=0.36$ and $658.51 \pm 433.1 \mathrm{~mm} 2$ vs. $755.14 \pm 470.6 \mathrm{~mm} 2, \mathrm{p}=0.22$, respectively) ${ }^{(21)}$ According to table no 7 , hematuria is significant to our study during urine analysis on ultrasound examination. We included 71 patients, Hematuria was present in16(23\%).Hydronephrosis was increased in9(13\%),hydronephrosis of right kidney was increased in 2(2.8\%) and bilateral increased hydronephrosis was noticed in 5(7\%) patients. Similar results seen in study conducted by Mehmat Fati Inci et.al in (2013) performed prospective cross sectional study on the relation of hydronephrosis with microhematuria. They included 86 patients, with a mean age of $42.1 \pm 14.4$ years; $48(57.8 \%)$ were females and $35(42.2 \%)$ were males. Detection of 5 or more red cells on urinalysis was regarded as microscopic hematuria, and was positive in 46 patients $(55.4 \%)$. There was a statistically significant difference in presence of hydronephrosis between the microhematuria (36 patients, $78 \%$ ) and non-microhematuria (12 patients, $32 \%)$ groups $(\mathrm{p}<0.001)^{(22)}$ According to table no 8 , pus cells is significant to our study during urine analysis on ultrasound examination. We included 71 patients, out of these patients Pyrexia was present in $27(38 \%)$ patients, 11(15.4\%) patients had many pus cells , 12(17\%) patients had fewer pus cells. Similar results seen in study conducted by Dennies L. Steven et.al in (2019) was performed prospective cross sectional study on a streptoccocal infection leads to pyrexia. They included 20 patients median age, 36). 16 (80 percent) had renal impairment, and 11 (55 percent) had acute respiratory distress syndrome. The mortality rate was 30 percent. All patients but 1 had positive tissue cultures for Streptococcus pyogenes; 12 had positive blood cultures. ${ }^{(23)}$ 


\subsubsection{Results}

\begin{tabular}{|l|l|r|r|}
\hline \multicolumn{2}{|c|}{ Statistics } \\
\hline \multirow{2}{*}{$\mathrm{N}$} & Valid & Gender & Age \\
\cline { 2 - 4 } & Missing & 71 & 71 \\
\hline Mean & & 0 & 0 \\
\hline Median & & .32 & 30.21 \\
\hline Std. Deviation & 25 & .00 & 15.00 \\
\hline Percentiles & 50 & .00 & 29.00 \\
\cline { 2 - 4 } & 75 & .00 & 38.00 \\
\cline { 2 - 4 } & & 1.00 & $55.00 \mathrm{e}$ \\
\hline
\end{tabular}

\section{Table 1: Descriptive statistics of}

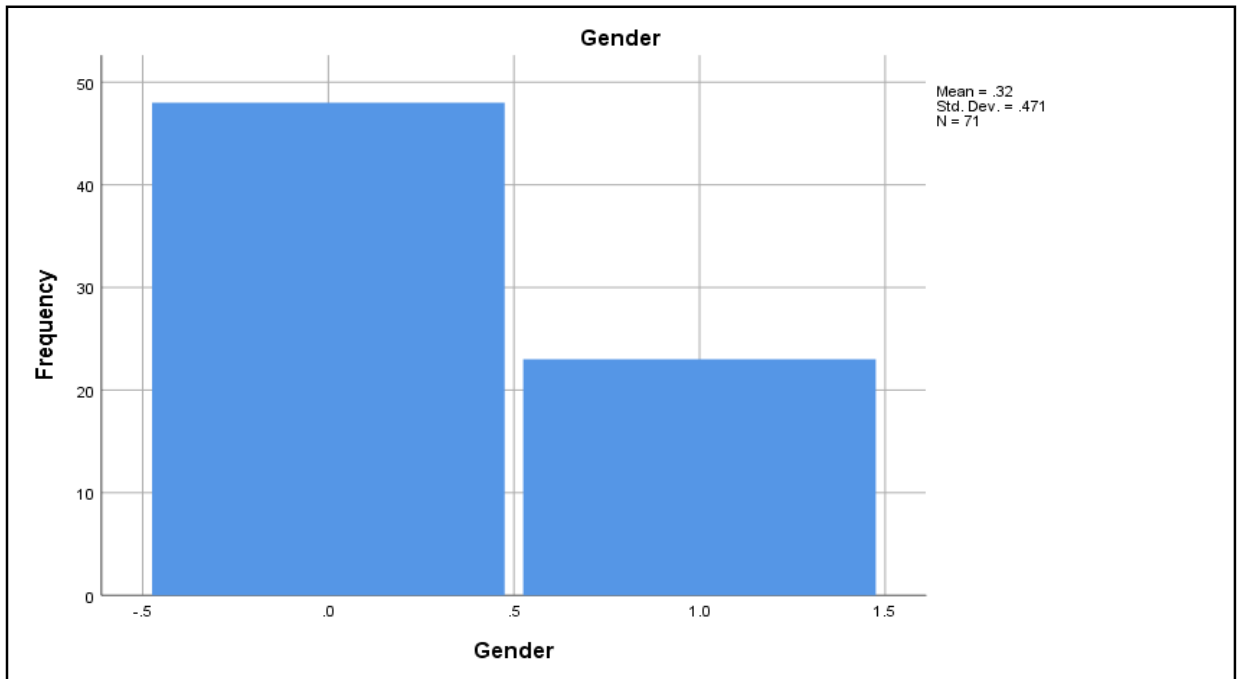

In this descriptive cross-sectional study through non-conventional sampling technique, we have selected total 71 patients, in which after statistical analysis the maximum range was about 65 and the minimum age of the patients included in the study was about 23 and maximum age was around 40 with the common standard deviation to be around 15.881

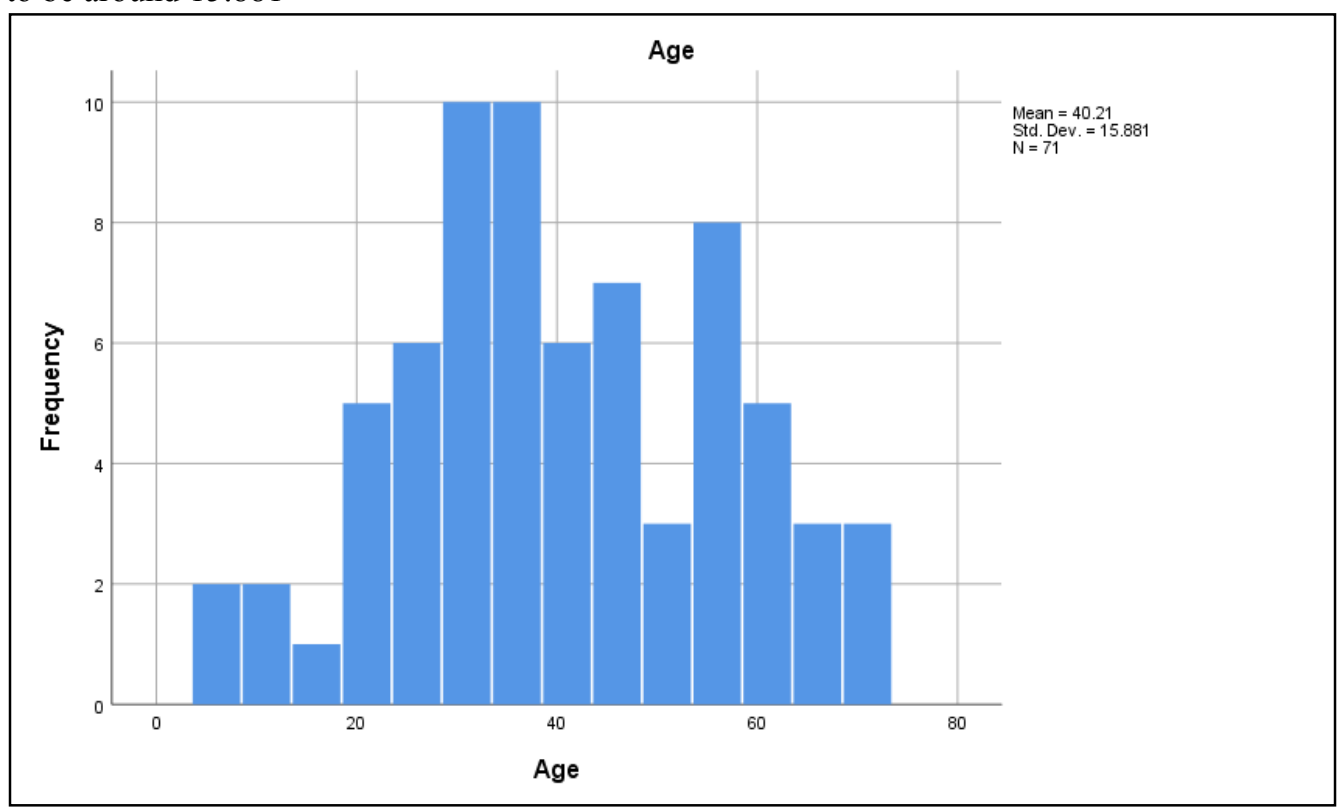

According to table no 1, urine analysis out of 71 patients creatinine level was increased in $17(23 \%)$ patients on ultrasound examination out of these $17(23 \%)$ patients renal echogenicity was normal in $4(5.6 \%)$ patients, echogenicity of right kidney was increased in 1(1.4\%)patient, echogenicity of left kidney was increased in 0 patient and bilateral increased echogenicity was noticed in $12(17 \%)$ patients. 


\begin{tabular}{|c|c|c|c|c|c|c|}
\hline \multicolumn{7}{|c|}{ Case Processing Summary } \\
\hline & \multirow{2}{*}{\multicolumn{4}{|c|}{$\begin{array}{ll} & \text { Cases } \\
\text { Valid } & \text { Missing }\end{array}$}} & \multirow{2}{*}{\multicolumn{2}{|c|}{ Total }} \\
\hline & & & & & & \\
\hline & $\mathrm{N}$ & Percent & $\mathrm{N}$ & Percent & $\mathrm{N}$ & Percent \\
\hline Creatinine $*$ Echogenecity & 7 & $100.0 \%$ & 0 & $0.0 \%$ & 71 & $100.0 \%$ \\
\hline
\end{tabular}

Count

\section{Creatinine * Echogenecity Crosstabulation}

\begin{tabular}{|c|c|c|c|c|c|c|}
\hline & & \multicolumn{4}{|c|}{ Echogenecity } & \multirow[b]{4}{*}{ Total } \\
\hline & & & Right sided & Left sided & Both sided & \\
\hline & & & Increased & Increased & Increased & \\
\hline & & Normal & Echogenecity & Echogenecity & Echogenecity & \\
\hline \multirow[t]{2}{*}{ Creatinine } & Normal & 35 & 5 & 1 & 13 & 54 \\
\hline & Increased & 4 & 1 & 0 & 12 & 17 \\
\hline Total & & 39 & 6 & 1 & 25 & 71 \\
\hline
\end{tabular}

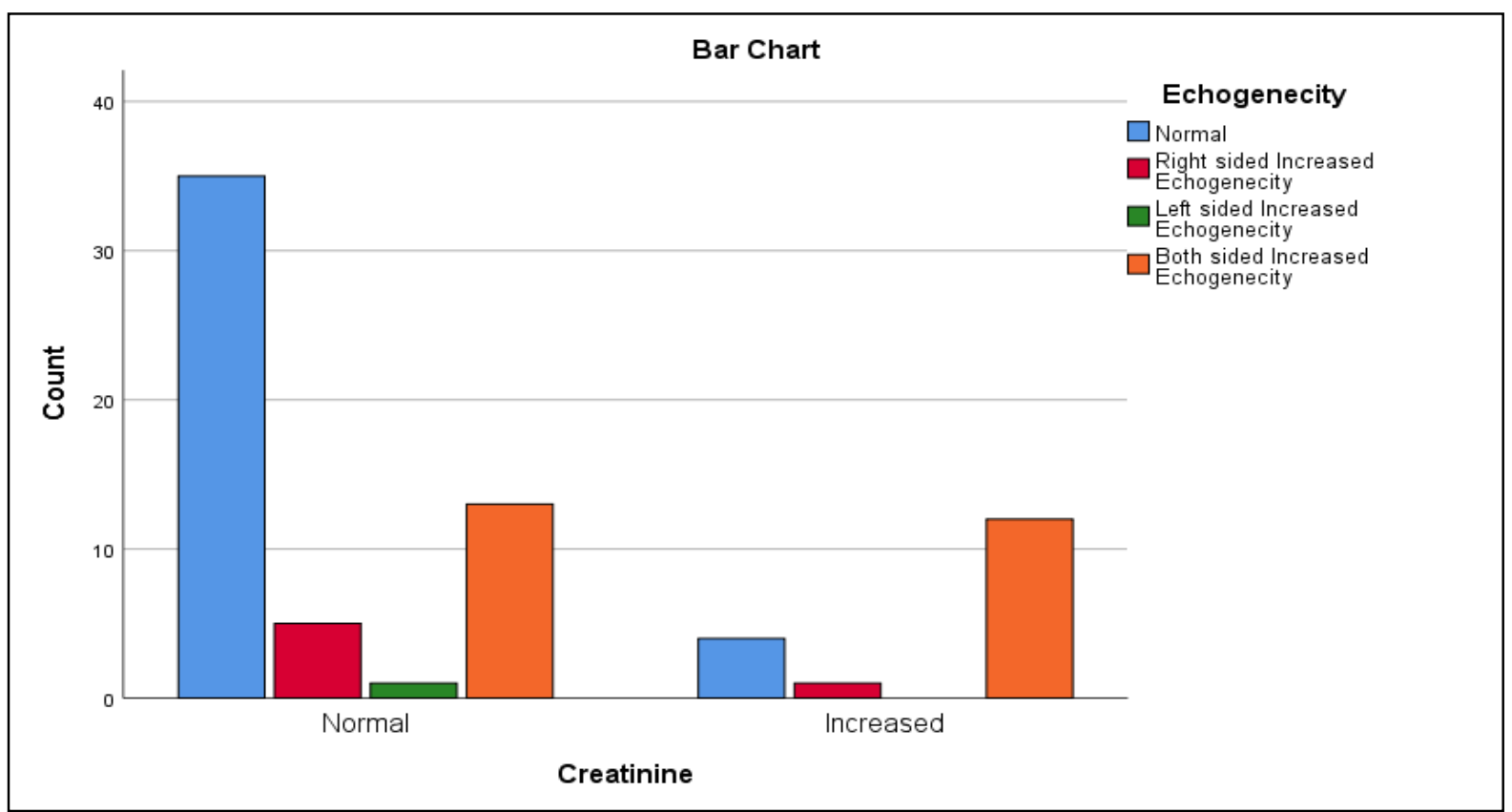

Table 1:A bar chart representation of data betweenc creatinine and echogenicity

According to table number 2, urine analysis out of 71 patients serum urea level was abnormal in $42(59 \%)$ patients on ultrasound examination out of these 42 patients renal echogencity was normal in $17(23 \%)$, echogencity of right kidney was increased in 4(5.6\%) patients , echogencity of left kidney was increased in 1(1.4\%) patient and bilateral increased echogencity was noticed in $20(28 \%)$ patients

\section{Crosstabs}

\section{Case Processing Summary}

\begin{tabular}{|c|c|c|c|c|c|c|}
\hline & \multicolumn{4}{|c|}{ Cases } & \multirow{2}{*}{\multicolumn{2}{|c|}{ Total }} \\
\hline & $\mathrm{Va}$ & & Mis & & & \\
\hline & $\mathrm{N}$ & Percent & $\mathrm{N}$ & Percent & $\mathrm{N}$ & Percent \\
\hline Urea * Echogenecity & 71 & $100.0 \%$ & 0 & $0.0 \%$ & 71 & $100.0 \%$ \\
\hline
\end{tabular}

Count

\section{Urea * Echogenecity Crosstabulation}

\begin{tabular}{|c|c|c|c|c|c|c|}
\hline & \multicolumn{5}{|c|}{ Echogenecity } & \multirow[b]{2}{*}{ Total } \\
\hline & & Normal & $\begin{array}{l}\text { Right sided } \\
\text { Increased } \\
\text { Echogenecity }\end{array}$ & $\begin{array}{l}\text { Left sided } \\
\text { Increased } \\
\text { Echogenecity }\end{array}$ & $\begin{array}{l}\text { Both sided } \\
\text { Increased } \\
\text { Echogenecity }\end{array}$ & \\
\hline \multirow[t]{2}{*}{ Urea } & Normal & 22 & 2 & 0 & 5 & 29 \\
\hline & Abnormal & 17 & 4 & 1 & 20 & 42 \\
\hline Total & & 39 & 6 & 1 & 25 & 71 \\
\hline
\end{tabular}




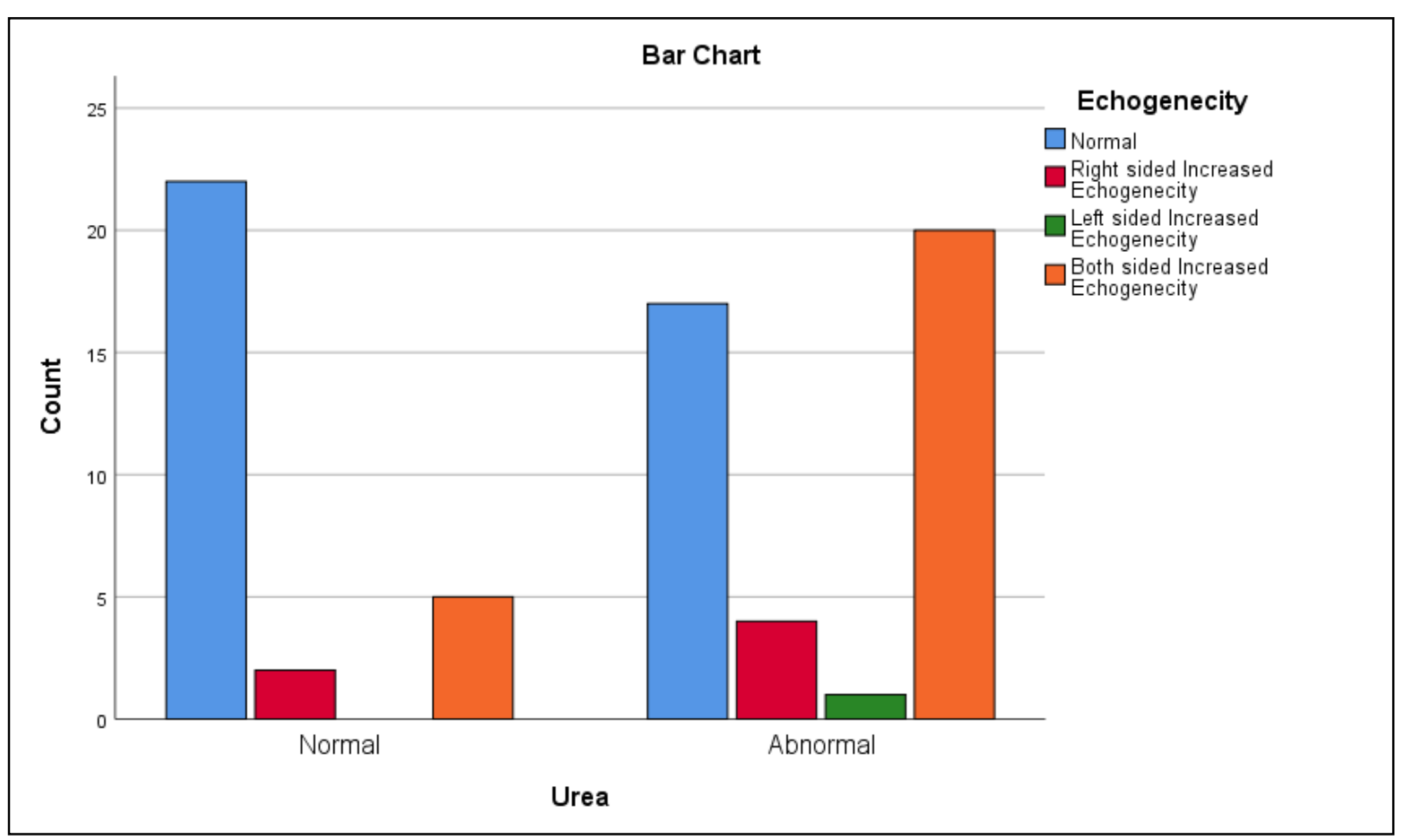

Table 2: A bar chart representation of data between urea and echogenicity

According to table no 3, urine analysis out of 71 patients $\mathrm{CaO}$ Crystal level was present in $20(28 \%)$ patients on ultrasound examination out of these 20 patients hydronephrosis was increased in 11(15.4\%) patients, hydronehprosis of right kidney was increased in 4(5.6\%) patient, hydronephrosis of left kidney was increased in $2(2.8 \%)$ patient and bilateral increased hydronehprosis was noticed in $3(4.2 \%)$ patients

Case Processing Summary

\begin{tabular}{|c|c|c|c|c|c|c|c|c|}
\hline & \multicolumn{8}{|c|}{ Cases } \\
\hline & \multicolumn{3}{|c|}{ Valid } & \multicolumn{2}{|c|}{ Missing } & \multicolumn{3}{|c|}{ Total } \\
\hline & $\mathrm{N}$ & & Percent & $\mathrm{N}$ & Percent & $\mathrm{N}$ & & Percent \\
\hline CaO Crystal $*$ Hydronephrosis & & 71 & $100.0 \%$ & & $0.0 \%$ & & 71 & $100.0 \%$ \\
\hline
\end{tabular}

Count

\section{CaO Crystal * Hydronephrosis Crosstabulation}

\begin{tabular}{|c|c|c|c|c|c|c|}
\hline & & \multicolumn{4}{|c|}{ Hydronephrosis } & \multirow[b]{2}{*}{ Total } \\
\hline & & Absent & $\begin{array}{c}\text { Right side } \\
\text { increased } \\
\text { Hydronephrosis }\end{array}$ & $\begin{array}{c}\text { Left side } \\
\text { increased } \\
\text { Hydronephrosis }\end{array}$ & $\begin{array}{c}\text { Both side } \\
\text { increased } \\
\text { Hydronephrosis }\end{array}$ & \\
\hline \multirow[t]{3}{*}{$\mathrm{CaO}$ Crystal } & Nill & 20 & 6 & 9 & 15 & 50 \\
\hline & Present & 11 & 4 & 2 & 3 & 20 \\
\hline & Excceded & 1 & 0 & 0 & 0 & 1 \\
\hline Total & & 32 & 10 & 11 & 18 & 71 \\
\hline
\end{tabular}




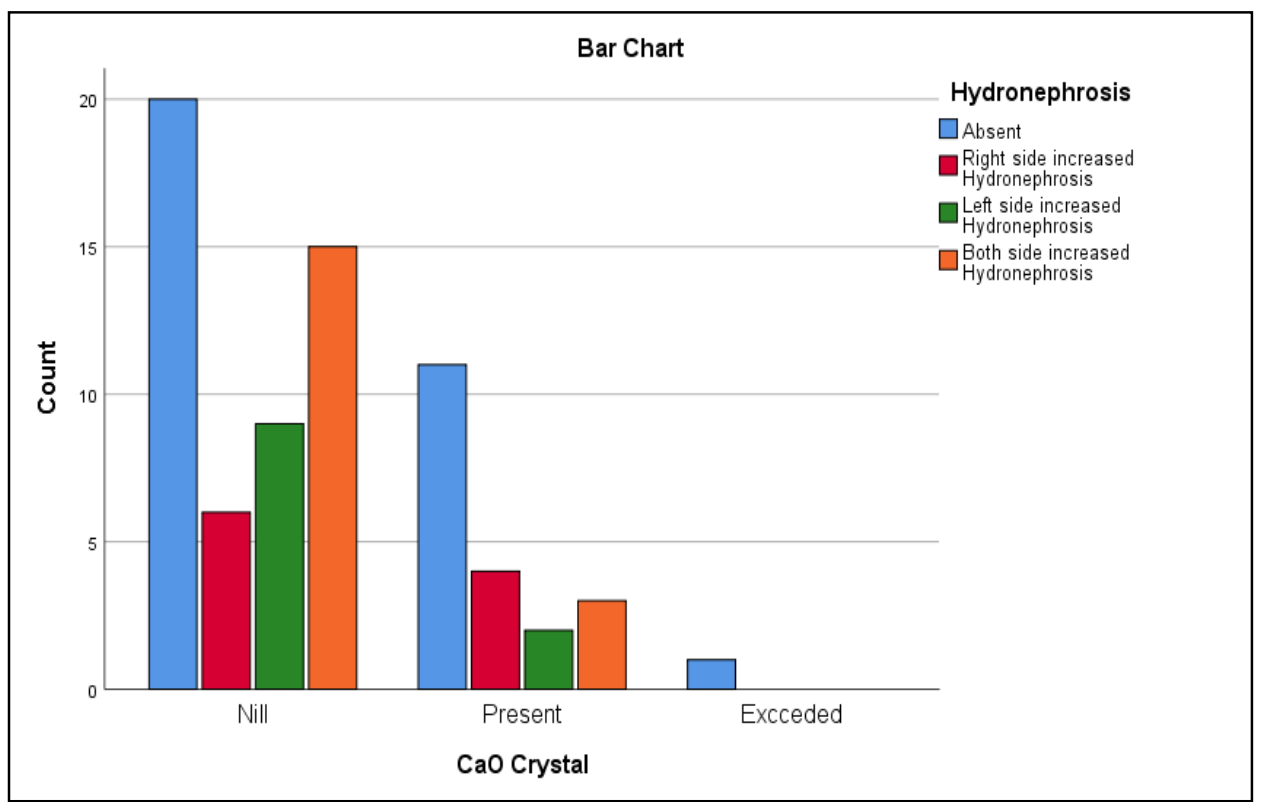

Table 3:A bar chart representation of data between $\mathrm{CaO}$ crystal and hydronephrosis

According to table no 4, urine analysis out of 71 patients urinary bladder wall thickness was normal in $19(26.7 \%)$ patients on ultrasound examination out of these 19 patients urinary bladder wall thickness was abnormal in $15(21.1 \%)$ patients , burning micturation was present in $4(5.6 \%)$ patients.

Crosstabs

\begin{tabular}{|c|c|c|c|c|c|c|c|c|}
\hline \multicolumn{9}{|c|}{ Case Processing Summary } \\
\hline & & & \multirow{2}{*}{\multicolumn{2}{|c|}{ Valid }} & \multirow{2}{*}{\multicolumn{2}{|c|}{$\begin{array}{l}\text { Cases } \\
\text { Missing }\end{array}$}} & \multirow{2}{*}{\multicolumn{2}{|c|}{ Total }} \\
\hline & & & & & & & & \\
\hline & & & $\mathrm{N}$ & Percent & $\mathrm{N}$ & Percent & $\mathrm{N}$ & Percent \\
\hline $\begin{array}{l}\text { Urinary } \\
\text { Thickness } \\
\text { Micturation }\end{array}$ & $\underset{*}{\text { Bladdar }}$ & $\begin{array}{r}\text { Wall } \\
\text { Burning }\end{array}$ & 71 & $100.0 \%$ & 0 & $0.0 \%$ & 7 & $100.0 \%$ \\
\hline
\end{tabular}

Count

\section{Urinary Bladdar Wall Thickness * Burning Micturation Crosstabulation}

\begin{tabular}{|c|c|c|c|c|}
\hline & & \multicolumn{2}{|c|}{ Burning Micturation } & \multirow[b]{2}{*}{ Total } \\
\hline & & Absent & Present & \\
\hline \multirow[t]{2}{*}{ Urinary Bladdar Wall Thickness } & Normal & 47 & 5 & 52 \\
\hline & Abnormal & 15 & 4 & 19 \\
\hline Total & & 62 & 9 & 71 \\
\hline
\end{tabular}

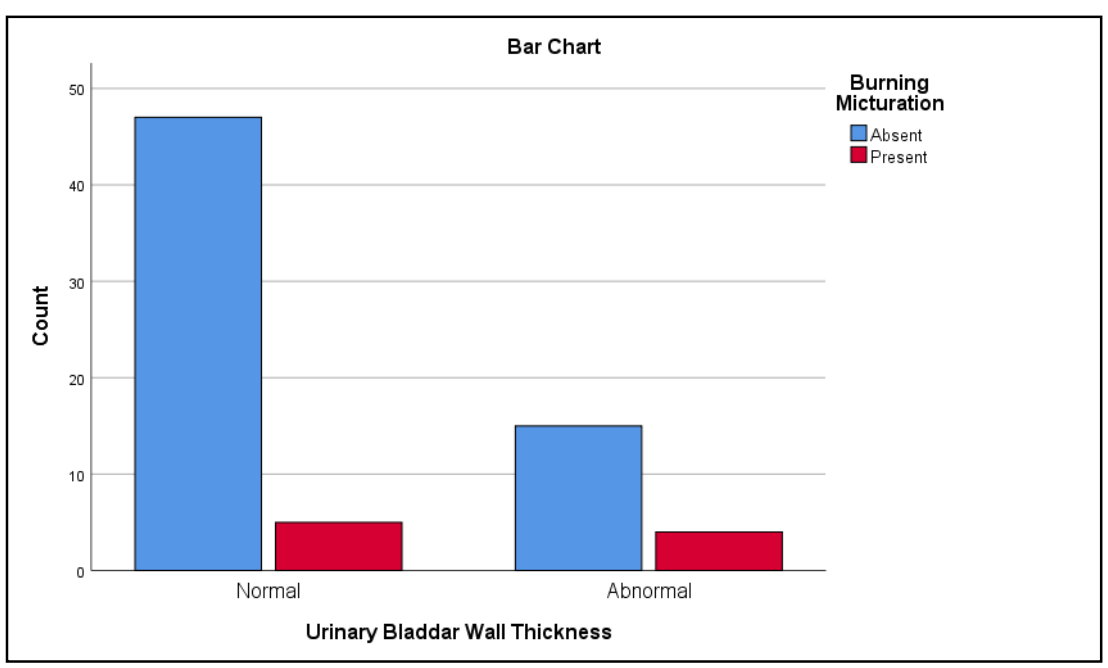

Table 4:A bar chart representation of data between bladder wall thickness and burnig micturition 
According to table no 5,according to urine analysis out of these 71 patients hematuria was present in $16(22.5 \%)$ patients on ultrasound examination out of these $16(22.5 \%)$ patients, many RBCs present in $12(17 \%)$ patients, $2(2.8 \%)$ patients have fewer RBCs and $2(2.8 \%)$ have nill RBCs

\section{Crosstabs}

\section{Case Processing Summary}

\begin{tabular}{|c|c|c|c|c|c|c|}
\hline & \multicolumn{4}{|c|}{ Cases } & \multirow{2}{*}{\multicolumn{2}{|c|}{ Total }} \\
\hline & \multicolumn{2}{|c|}{ Valid } & \multicolumn{2}{|c|}{ Missing } & & \\
\hline & $\mathrm{N}$ & Percent & $\mathrm{N}$ & Percent & $\mathrm{N}$ & Percent \\
\hline Hematuria * RBCs & 71 & $100.0 \%$ & 0 & $0.0 \%$ & 71 & $100.0 \%$ \\
\hline
\end{tabular}

Count

\section{Hematuria * RBCs Crosstabulation}

\begin{tabular}{|c|c|c|c|c|c|}
\hline & & \multicolumn{3}{|c|}{ RBCs } & \multirow[b]{2}{*}{ Total } \\
\hline & & Nill & Many & Few & \\
\hline \multirow[t]{2}{*}{ Hematuria } & Absent & 23 & 23 & 9 & 55 \\
\hline & Present & 2 & 12 & 2 & 16 \\
\hline Total & & 25 & 35 & 11 & 71 \\
\hline
\end{tabular}

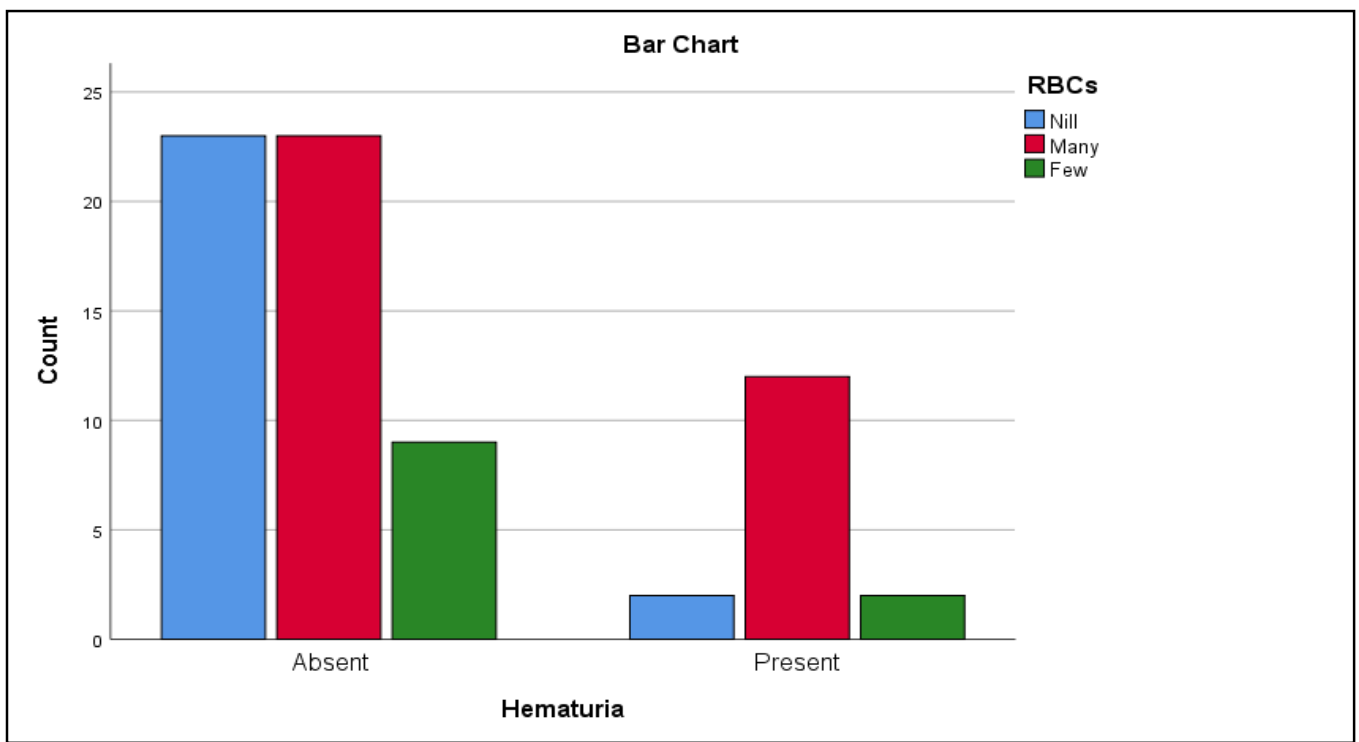

\section{Table 5:A bar chart representation of data between hematuria and RBCs}

According to table no 6, a total of 71 patients were included in our study according to urine analysis out of these 71 patients Pus Cells was increased in 26(36.6\%) patients on ultrasound examination out of these 26(36.6\%) patients hydronephrosis was increased in $11(15.4 \%)$ patients, Hydrnephrosis of right kidney was increased in $6(8.4 \%)$ patient, hydronephrosis of left kidney was increased in $3(4.2 \%)$ patient and bilateral increased hydronephrosis was noticed in 6(8.4\%) patients

\begin{tabular}{|c|c|c|c|c|c|c|}
\hline & $\mathrm{Ca}$ & Processing & nmary & & & \\
\hline & & & $\mathrm{Ca}$ & & & \\
\hline & & & Mis & & & \\
\hline & $\mathrm{N}$ & Percent & $\mathrm{N}$ & Percent & $\mathrm{N}$ & Percent \\
\hline Pus Cells * Hydronephrosis & 71 & $100.0 \%$ & 0 & $0.0 \%$ & 71 & $100.0 \%$ \\
\hline
\end{tabular}

Count

\section{Pus Cells * Hydronephrosis Crosstabulation}

\begin{tabular}{|c|c|c|c|c|c|c|}
\hline & & \multicolumn{4}{|c|}{ Hydronephrosis } & \multirow[b]{2}{*}{ Total } \\
\hline & & Absent & $\begin{array}{l}\text { Right side increased } \\
\text { Hydronephrosis }\end{array}$ & $\begin{array}{l}\text { Left side increased } \\
\text { Hydronephrosis }\end{array}$ & $\begin{array}{c}\text { Both side increased } \\
\text { Hydronephrosis }\end{array}$ & \\
\hline \multirow{3}{*}{$\begin{array}{l}\text { Pus } \\
\text { Cells }\end{array}$} & Nill & 5 & 2 & 2 & 3 & 12 \\
\hline & Many & 16 & 2 & 6 & 9 & 33 \\
\hline & Few & 11 & 6 & 3 & 6 & 26 \\
\hline Total & & 32 & 10 & 11 & 18 & 71 \\
\hline
\end{tabular}




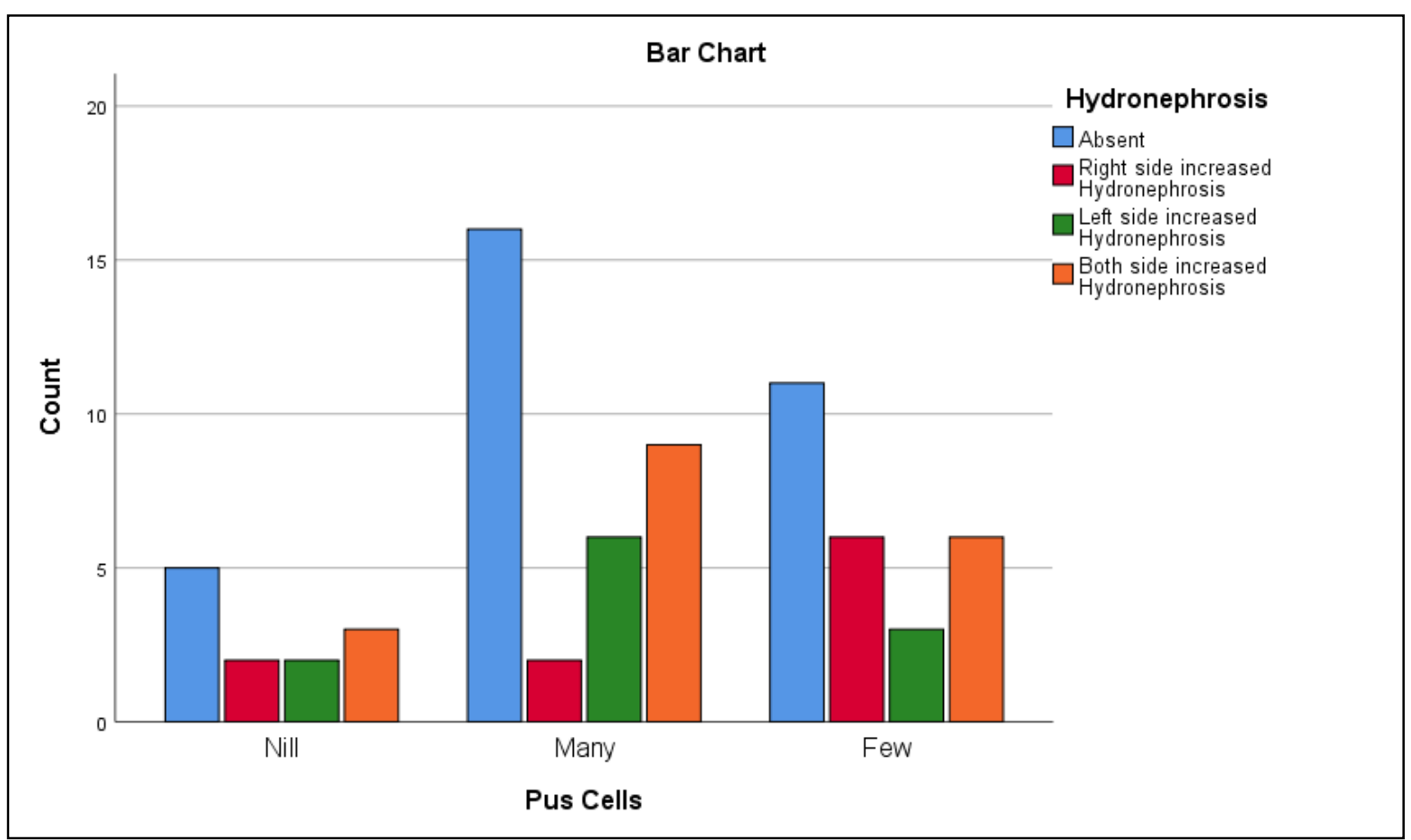

Table 6: A bar chart representation of data between pus cells and hydronephrosis

According to table no 7, a total of 71 patients were included in our study according to urine analysis out of these 71 patients Hematuria was present in 16(22.5\%) patients on ultrasound examination out of these 16 patients hydronephrosis was increased in $9(12.6 \%)$ patients, hydronephrosis of right kidney was increased in $2(2.8 \%)$ patient, hydronephrosis of left kidney was increased in 0 patient and bilateral increased hydronephrosis was noticed in $5(7 \%)$ patients.

\section{Crosstabs}

Case Processing Summary

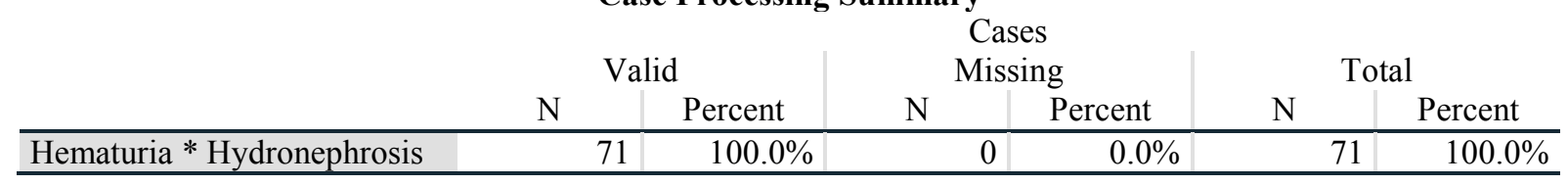

Count

\section{Hematuria * Hydronephrosis Crosstabulation}

\begin{tabular}{|c|c|c|c|c|c|c|}
\hline & & \multicolumn{4}{|c|}{ Hydronephrosis } & \multirow[b]{2}{*}{ Total } \\
\hline & & Absent & $\begin{array}{c}\text { Right side } \\
\text { increased } \\
\text { Hydronephrosis }\end{array}$ & $\begin{array}{c}\text { Left side } \\
\text { increased } \\
\text { Hydronephrosis }\end{array}$ & $\begin{array}{c}\text { Both side } \\
\text { increased } \\
\text { Hydronephrosis }\end{array}$ & \\
\hline \multirow[t]{2}{*}{ Hematuria } & Absent & 23 & 8 & 11 & 13 & 55 \\
\hline & Present & 9 & 2 & 0 & 5 & 16 \\
\hline Total & & 32 & 10 & 11 & 18 & 71 \\
\hline
\end{tabular}




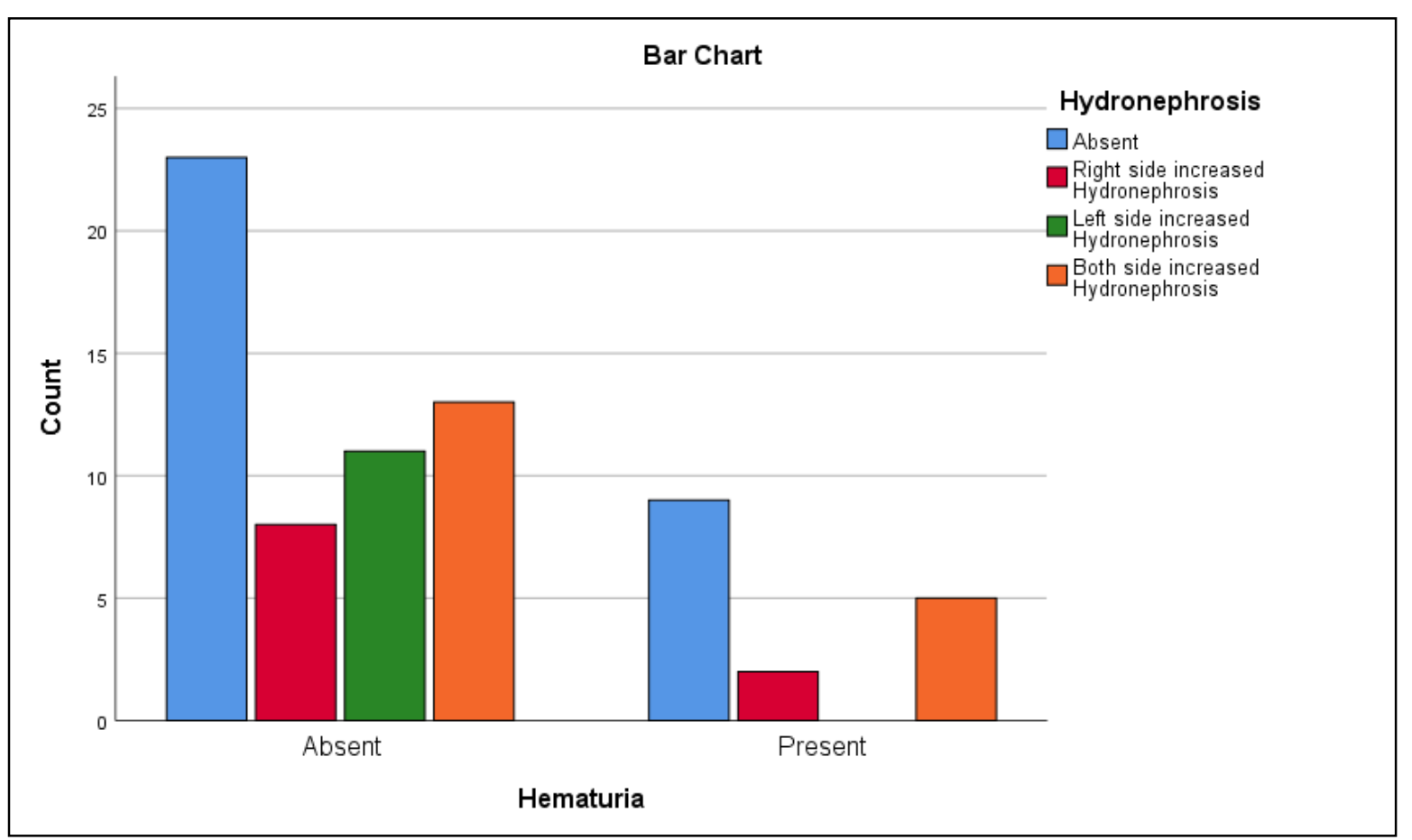

Table 7; A bar chart representation of data between hematuria and hydronephrosis

According to table no 8, a total of 71 patients were included in our study according to urine analysis out of these 71 patients fever was present in 27 patients on ultrasound examination out of these 27(38\%) patients, 11(15.4\%) patients had many pus cells , 12(17\%) patients had fewer pus cells and 4(5.6\%) patients had nill pus cells

\section{Crosstabs}

\begin{tabular}{|c|c|c|c|c|c|c|c|c|}
\hline \multirow{2}{*}{\multicolumn{9}{|c|}{ Case Processing Summary }} \\
\hline & & & & & & & & \\
\hline & \multicolumn{3}{|c|}{ Valid } & \multicolumn{2}{|c|}{$\begin{array}{l}\text { Cases } \\
\text { Missing }\end{array}$} & \multicolumn{3}{|c|}{ Total } \\
\hline & $\mathrm{N}$ & & Percent & $\mathrm{N}$ & Percent & $\mathrm{N}$ & & Percent \\
\hline Fever * Pus Cells & & 71 & $100.0 \%$ & & $0.0 \%$ & & 71 & $100.0 \%$ \\
\hline
\end{tabular}

Count

\section{Fever * Pus Cells Crosstabulation}

\begin{tabular}{llr|c|c|r|r} 
& \multicolumn{5}{c}{ Pus Cells } & \multicolumn{2}{c}{ Total } \\
\hline Fever & Nill & & Many & Few & \multicolumn{2}{c}{ Tot } \\
& Absent & 8 & 22 & 14 & 44 \\
\hline Total & Present & 4 & 11 & 12 & 27 \\
\hline
\end{tabular}




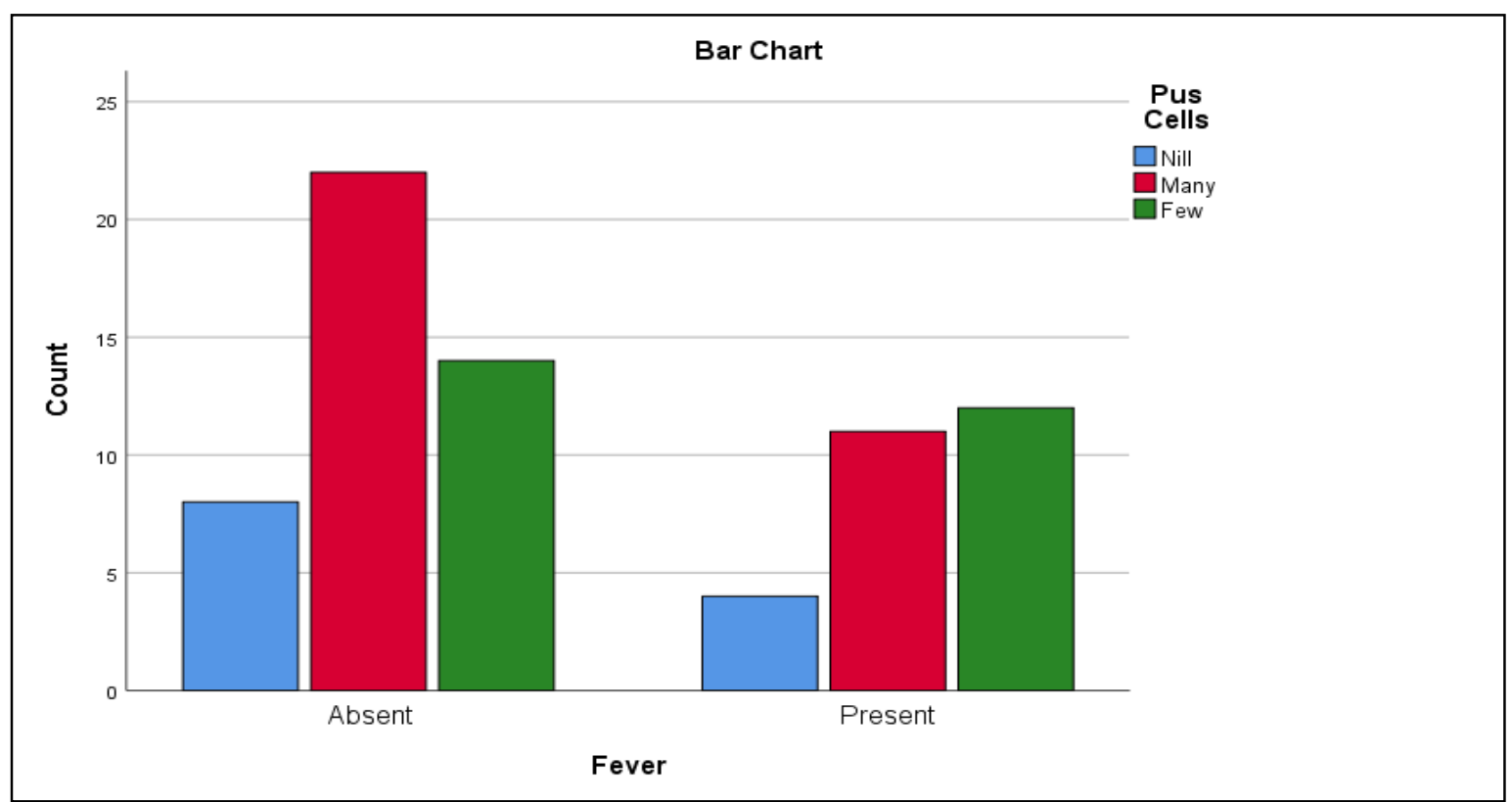

Table 8: A bar chart representation of data between pus cells and pyrexia

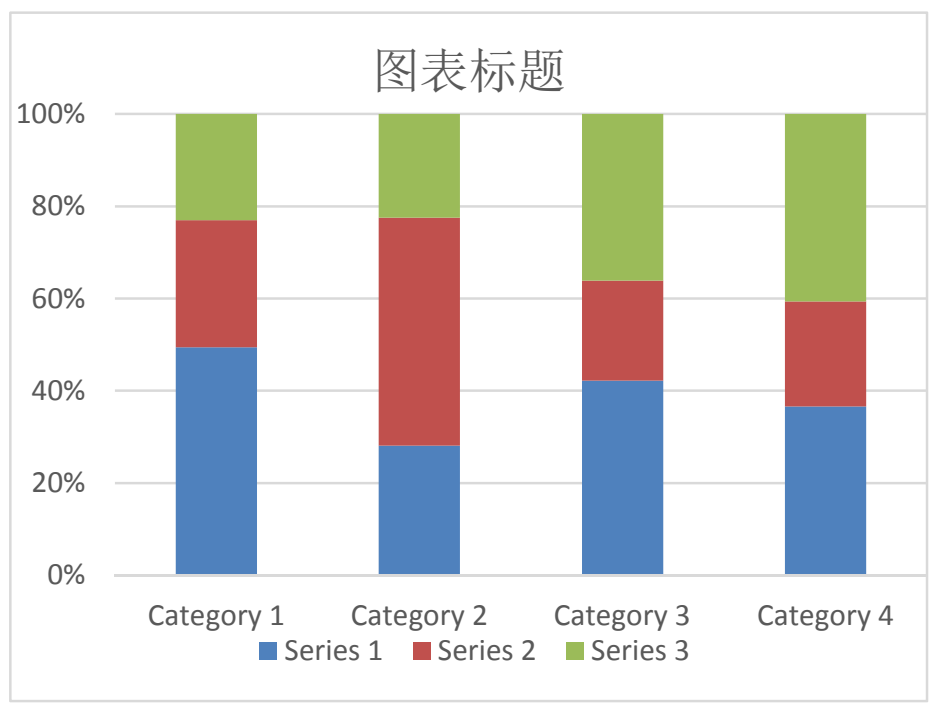

\section{REFERENCES:}

1. Idrizi A, Barbullushi M, Petrela E, Kodra S, Koroshi A, Thereska N. The influence of renal manifestations to the progression of autosomal dominant polycystic kidney disease. Hippokratia. 2009;13(3):161.

2. Geerlings SE. Clinical presentations and epidemiology of urinary tract infections. Urinary Tract Infections: Molecular Pathogenesis and Clinical Management. 2017:27-40.

3. Gounden V, Jialal I. Renal function tests. 2018.

4. Di Micco L, Quinn RR, Ronksley PE, Bellizzi V, Lewin AM, Cianciaruso B, et al. Urine creatinine excretion and clinical outcomes in CKD. Clinical Journal of the American Society of Nephrology. 2013;8(11):187783.

5. Nauka PC, Galen BT. The Focused Assessment with Sonography in Cancer (FASC) Examination. POCUS Journal. 2020;5(2):42-5.

6. Strasinger SK, Di Lorenzo MS. Urinalysis and body fluids: FA Davis; 2014

7. Rensburg B, Meyers A. Clinical aspects of chronic kidney disease. South African Medical Journal. 2015;105:237.

8. Tzimenatos L, Mahajan P, Dayan PS, Vitale M, Linakis JG, Blumberg S, et al. Accuracy of the urinalysis for urinary tract infections in febrile infants 60 days and younger. Pediatrics. 2018;141(2).

9. Dreyer G. Examining the urine-what can it tell us at the bed-side? Malawi medical journal: the journal of Medical Association of Malawi. 2010;22(4):126. 
10. Echeverry G, Hortin GL, Rai AJ. Introduction to urinalysis: historical perspectives and clinical application. the Urinary Proteome. 2010:1-12.

11. Kaplan BS, Pradhan M. Urinalysis interpretation for pediatricians. Pediatric annals. 2013;42(3):e45-e51.

12. Beland MD, Walle NL, Machan JT, Cronan JJ. Renal cortical thickness measured at ultrasound: is it better than renal length as an indicator of renal function in chronic kidney disease? American Journal of Roentgenology. 2010;195(2):W146-W9.

13. Yang H, Wang Q, Luo J, Li Q, Wang L, LI CC, et al. Ultrasound of urinary system and urinary screening in 14256 asymptomatic children in China. Nephrology. 2010;15(3):362-7.

14. Chan V, Perlas A. Basics of ultrasound imaging. Atlas of ultrasound-guided procedures in interventional pain management: Springer; 2011. p. 13-9.

15. Baloch N, Hasan OH, Jessar MM, Hattori S, Yamada S. "Sports Ultrasound", advantages, indications and limitations in upper and lower limbs musculoskeletal disorders. Review article. International Journal of Surgery. 2018;54:333-40.

16. Siddappa JK, Singla S, Mohammed Al Ameen S, Kumar N. Correlation of ultrasonographic parameters with serum creatinine in chronic kidney disease. Journal of clinical imaging science. 2013;3.

17. Anakwue A-MC, Idigo FU, Anakwue RC. Renal echotextural changes in Nigerian workers chronically exposed to petroleum-based liquid fuels. Journal of ultrasonography. 2020;20(80):e18.

18. Khan SR. Crystal-induced inflammation of the kidneys: results from human studies, animal models, and tissue-culture studies. Journal of Clinical and Experimental Nephrology. 2004;8(2):75-88.

19. Joudi M, Fathi M, Hiradfar M. Incidence of asymptomatic meatal stenosis in children following neonatal circumcision. Journal of pediatric urology. 2011;7(5):526-8.

20. Peacock PR, Souto HL, Penner GE, Dalsey WC, Becher JW, Kaplan JL. What is gross hematuria? Correlation of subjective and objective assessment. Journal of Trauma and Acute Care Surgery. 2001;50(6):1060-2.

21. Erdogan A, Sambel M, Caglayan V, Avci S. Importance of the Hounsfield Unit Value Measured by Computed Tomography in the Differentiation of Hydronephrosis and Pyonephrosis. Cureus. 2020;12(11).

22. Inci MF, Ozkan F, Bozkurt S, Sucakli MH, Altunoluk B, Okumus M. Correlation of volume, position of stone, and hydronephrosis with microhematuria in patients with solitary urolithiasis. Medical science monitor: international medical journal of experimental and clinical research. 2013;19:295.

23. Stevens DL, Tanner MH, Winship J, Swarts R, Ries KM, Schlievert PM, et al. Severe group A streptococcal infections associated with a toxic shock-like syndrome and scarlet fever toxin A. New England journal of medicine. 1989;321(1):1-7. 